\title{
Low CD36 and LOX-1 Levels and CD36 Gene Subexpression Are Associated with Metabolic Dysregulation in Older Individuals with Abdominal Obesity
}

\author{
Perla-Monserrat Madrigal-Ruíz, ${ }^{1,2,3}$ Rosa-Elena Navarro-Hernández, ${ }^{1,2,3}$ \\ Sandra-Luz Ruíz-Quezada, ${ }^{3,4}$ Fernanda-Isadora Corona-Meraz, \\ Mónica Vázquez-Del Mercado, ${ }^{1,2,5,6}$ Eduardo Gómez-Bañuelos, ${ }^{2,3,6}$ \\ Jorge Castro-Albarran, ${ }^{2,3}$ Flavio Sandoval-García, ${ }^{2,7}$ \\ Luis-Javier Flores-Alvarado, ${ }^{1,3}$ and Beatriz-Teresita Martín-Marquez ${ }^{1,2,6}$ \\ ${ }^{1}$ Departamento de Biología Molecular y Genómica, Centro Universitario de Ciencias de la Salud, Universidad de Guadalajara, \\ Sierra Mojada No. 950, Colonia Independencia, 44340 Guadalajara, JAL, Mexico \\ ${ }^{2}$ Instituto de Investigación en Reumatología y del Sistema Músculo Esquelético, Centro Universitario de Ciencias de la Salud, \\ Universidad de Guadalajara, Sierra Mojada No. 950, Colonia Independencia, 44340 Guadalajara, JAL, Mexico \\ ${ }^{3} U D G$-CA-701, Grupo de Investigación Inmunometabolismo en Enfermedades Emergentes (GIIEE), Centro Universitario de \\ Ciencias de la Salud, Universidad de Guadalajara, Sierra Mojada No. 950, Colonia Independencia, 44340 Guadalajara, JAL, Mexico \\ ${ }^{4}$ Departamento de Farmacobiología, Centro Universitario de Ciencias Exactas e Ingenierías, Universidad de Guadalajara, \\ Boulevard Marcelino García Barragán No. 1421, 44430 Guadalajara, JAL, Mexico \\ ${ }^{5}$ Servicio de Reumatología, División de Medicina Interna, Hospital Civil “Dr. Juan I. Menchaca”, Universidad de Guadalajara, \\ Salvador de Quevedo y Zubieta No. 750, 44340 Guadalajara, JAL, Mexico \\ ${ }^{6}$ UDG-CA-703, Grupo de Investigación en Inmunología y Reumatología, Centro Universitario de Ciencias de la Salud, \\ Universidad de Guadalajara, Sierra Mojada No. 950, Colonia Independencia, 44340 Guadalajara, JAL, Mexico \\ ${ }^{7}$ Departamento de Clínicas Médicas, Antiguo Hospital Civil de Guadalajara, Calle Hospital No. 320, \\ Colonia El Retiro, 44360 Guadalajara, JAL, Mexico
}

Correspondence should be addressed to Beatriz-Teresita Martín-Marquez; bethymar@hotmail.com

Received 5 February 2016; Revised 17 June 2016; Accepted 19 June 2016

Academic Editor: Hiroshi Okamoto

Copyright (C) 2016 Perla-Monserrat Madrigal-Ruíz et al. This is an open access article distributed under the Creative Commons Attribution License, which permits unrestricted use, distribution, and reproduction in any medium, provided the original work is properly cited.

Background. Obesity study in the context of scavenger receptors has been linked to atherosclerosis. CD36 and LOX-1 are important, since they have been associated with atherogenic and metabolic disease but not fat redistribution. The aim of our study was to determinate the association between CD36 and LOX-1 in presence of age and abdominal obesity. Methods. This is a crosssectional study that included 151 healthy individuals, clinically and anthropometrically classified into two groups by age $(<30$ and $\geq 30$ years old) and abdominal obesity (according to World Health Organization guidelines). We excluded individuals with any chronic and metabolic illness, use of medication, or smoking. Fasting blood samples were taken to perform determination of CD36 mRNA expression by real-time PCR, lipid profile and metabolic and low grade inflammation markers by routine methods, and soluble scavenger receptors (CD36 and LOX-1) by ELISA. Results. Individuals $\geq 30$ years old with abdominal obesity presented high atherogenic index, lower soluble scavenger receptor levels, and subexpression of CD36 mRNA (54\% less). On the other hand, individuals $<30$ years old with abdominal adiposity presented higher levels in the same parameters, except LOX-1 soluble levels. Conclusion. In this study, individuals over 30 years of age presented low soluble scavenger receptors levels pattern and CD36 gene subexpression, which suggest the chronic metabolic dysregulation in abdominal obesity. 


\section{Introduction}

Obesity is characterized by progressive enlargement of adipose tissue $[1,2]$. It has been shown that the fat distribution rather than total amount of fat is associated with increased cardiovascular disease (CVD) risk [3]. Since CD36 is a cell surface glycoprotein that belongs to class B scavenger receptor family, it is considered as multifunctional receptor: in adipocyte it acts as a fatty acid translocase of long-chain fatty acids; however, in monocyte/macrophage, it regulates oxLDL uptake [4]. On the other hand, LOX-1 is classified among E-type scavenger receptor family, is expressed in vascular endothelium, and recognizes oxLDL, cellular debris, and several structurally unrelated molecules as a ligand; it is highly expressed in the cardiovascular system by proinflammatory and prooxidative stimuli $[5,6]$.

LOX-1 and CD36 favor the development of atherosclerosis through their ability to bind and internalize modified LDL facilitating formation of macrophage foam cells and their location to subendothelial space promoting endothelial dysfunction and CVD.

Additionally, several studies associate an increase of soluble form of CD36 (sCD36) in symptomatic carotid stenosis with metabolic disorders, such as type 2 diabetes mellitus (T2DM). Meanwhile, the soluble form of LOX-1 (sLOX-1) has been mainly associated with diverse atherogenic diseases like arterial stiffness, T2DM, and myocardial infarction and it is even proposed as a biomarker for acute coronary syndrome [7-18]. Several studies showed an inflammatory paracrine interaction between adipocytes and macrophages which could be dependent on scavenger receptors; this pathogenic process involves a state of dysmetabolic profile and chronic inflammation which contributes to abdominal obesity development $[19,20]$.

However, the association of sCD36 and sLOX-1 levels with fat redistribution and metabolic markers is not known. The aim of our study was to determine the association between CD36 and LOX-1 in presence of age and abdominal obesity.

\section{Materials and Methods}

2.1. Subjects' Selection and Classification. In this crosssectional study, we recruited 151 adults aged between 20 and 59 years of general population of Mexico. They were classified according to the recommendations of World Health Organization Expert Consultation, by WC, waist-hip ratio (WHR), and waist-to-height ratio (WHtR), into two groups: the first group includes individuals with abdominal obesity, if any of the following conditions were present: $W C \geq 90.0 \mathrm{~cm}$, $\mathrm{WHR} \geq 0.90$, and $\mathrm{WHtR} \geq 0.525$ in men and $\mathrm{WC} \geq 80.0 \mathrm{~cm}$, $\mathrm{WHR} \geq 0.80$, and WHtR $\geq 0.530$ in women; the second group includes individuals without abdominal obesity, a group which has lower values of these measurements. In relation to age, an age of 30 years was established as a cutoff and two groups were stablished: $<30$ years old and $\geq 30$ years old.

We consider additional criteria for disease risk associations: BMI from 18.50 to $24.99 \mathrm{~kg} / \mathrm{m}^{2}$ was considered without disease risk; for increased disease risk: BMI 25.00 to $29.99 \mathrm{~kg} / \mathrm{m}^{2}$ plus WC $<102.0 \mathrm{~cm}$ (in men) or $<88.0 \mathrm{~cm}$ (in women) was considered; for high disease risk, we consider $\mathrm{WC} \geq 102.0 \mathrm{~cm}$ (in men) or $\geq 88.0 \mathrm{~cm}$ (in women) and BMI $\geq 30.0 \mathrm{~kg} / \mathrm{m}^{2}$ plus any WC measurement was classified as very high disease risk [21-23].

We included individuals who at the time of the study did not present with glucose intolerance, infectious diseases, hypertension, pregnancy, anemia, diagnosis of CVD, malignancy, and renal and metabolic diseases such as T2DM. We excluded subjects with current medication, smoking, or drugs use.

For ethics conduct before enrolment, participants were informed about the study and signed a consent form following Helsinki Declaration guidelines [24], and the institutional (Guadalajara University) review boards committees ensured appropriate ethical and biosecurity conduct.

2.2. Subjects' Medical History and Physical Examination. All individuals who satisfied inclusion criteria were clinically evaluated by a physician who performed a complete medical history; assessment of general health status and vital signs were included: blood pressure (executed 3 times with the subject in the sitting position and relaxing for 15 minutes before the measurement), heart, respiratory rate, and body temperature.

2.3. Subjects' Body Fat Storage Measurements. We evaluated the following body measurements: height was measured to the nearest $1 \mathrm{~mm}$ by using a stadiometer (seca $\mathrm{GmbH} \&$ Co. KG., Hamburg, Germany) and body weight, total body fat mass, and trunk body fat mass (absolute, $\mathrm{kg}$, and relative, \%) were determined by using bioelectrical impedance analysis (TANITA BC-418 segmental body composition analyzer, Tokyo, Japan) to the nearest $0.1 \mathrm{~kg}$. WC, hip circumference (HC), and coronal abdominal diameter were measured by using an anthropometric fiberglass tape (GULICK ${ }^{\circledR}$ length 0$180 \mathrm{~cm}$ precision \pm 0.1 , USA). At the level of the iliac crest (L45), sagittal abdominal diameter was measured using a slidingbeam, abdominal caliper (precision $\pm 0.1 \mathrm{~cm}$, Holtain Ltd., Crosswell, Crymych, Pembs., SA413UF, UK) with the patient lying in a supine position in the examination table [25-29]. Five measures of skinfold thicknesses (i.e., biceps, triceps, subscapular, suprailiac, and abdominal) were obtained on the right side of the body by using a Harpenden skinfold caliper (opened $80 \mathrm{~mm}$ and precision of $\pm 0.2 \mathrm{~mm}$, constant pressure: $10 \mathrm{~g} / \mathrm{mm}^{2}$; Holtain Ltd., Crosswell, Crymych, Pembs., SA41 3UF, UK). All these measurements were carried out by the same anthropometrist in duplicate following the procedures recommended by anthropometric indicators measurement guide $[30,31]$.

To determine obesity and adiposity indexes, the following math calculations were used, BMI, $\mathrm{kg} / \mathrm{m}^{2}=$ weight $(\mathrm{kg}) /$ height $^{2}(\mathrm{~m}) ; \mathrm{WHR}=\mathrm{WC} \mathrm{cm} / \mathrm{HC} \mathrm{cm} ; \mathrm{WHtR}=\mathrm{WC} \mathrm{cm} /$ height $(\mathrm{cm})$; conicity index $(\mathrm{CI})=\mathrm{WC}(\mathrm{cm}) / 0.109 \sqrt{ }$ weight $(\mathrm{kg}) /$ height $(\mathrm{cm})$; total adipose area $\left(\mathrm{TAA}, \mathrm{cm}^{2}\right)=\mathrm{WC}^{2} / 4 \pi$; visceral area $\left(\mathrm{VA}, \mathrm{cm}^{2}\right)=\pi(\mathrm{WC} / 2 \pi-\text { abdominal skinfold })^{2}$; 
subcutaneous abdominal area $\left(\mathrm{cm}^{2}\right)=$ TAA - VA [26]; visceral adipose index $(\mathrm{VAI})$ : for males, $\mathrm{VAI}=(\mathrm{WC} / 36.58+$ $(1.896 * \mathrm{BMI})$ )6(TG/0.81)6(1.52/HDLc), and for females, $\mathrm{VAI}=(\mathrm{WC} / 39.68+(1.886 * \mathrm{BMI})) 6(\mathrm{TG} / 1.03) 6(1.31 / \mathrm{HDLc})$; abdominal volume index $(\mathrm{AVI}, \mathrm{L})=\left[2 \times \mathrm{WC}^{2}+\right.$ $\left.(0.7 \mathrm{~cm})(\mathrm{WC}-\mathrm{HC})^{2} / 1000\right]$ [32]; and homeostasis model assessment-insulin resistance (HOMA-IR) $=[$ basal glucose $\mathrm{mg} / \mathrm{dL} \times($ basal insulin $\mu \mathrm{UI} / \mathrm{mL}) / 405]$ [33, 34], in addition to the sum of the 5 skin fold thicknesses (ST5) [35].

2.4. Metabolic and Inflammatory Markers and Scavenger Receptors Levels Measurements. We confirmed overnight fast of 12 hours in all subjects and obtained two venous blood samples, with and without anticoagulant (PAXgene ${ }^{\circledR}$ Blood RNA Tube CAT. 762165 and BD SST ${ }^{\mathrm{TM}}$ Plus $-13 \mathrm{~mm}$ CAT. 368159, BD Diagnostic Systems Montenegro 1402 (C1427AND), Buenos Aires, Argentina, resp.). Samples were allowed to clot for 30 minutes at $20^{\circ} \mathrm{C}$ before centrifugation for 10 minutes $/ 20^{\circ} \mathrm{C}$ at 1509 RCF (Rotanta $460 \mathrm{R}$, Andreas Hettich GmbH \& Co. KG.); serum was collected and stored immediately at $-86^{\circ} \mathrm{C}$ until further analysis.

We quantified serum concentration of basal glucose, $\mathrm{mg} / \mathrm{dL}$, and lipid profile, $\mathrm{mg} / \mathrm{dL}$, which included triglycerides, total cholesterol, HDLc, LDLc, and VLDLc [36] (high, low, and very low density lipoprotein cholesterols, resp.), apolipoproteins $\mathrm{Al}$ and $\mathrm{B}$ (Apo-Al and Apo-B), mg/dL, free fatty acids (FFA, mmol/mL), serum $\mathrm{C} 3, \mathrm{mg} / \mathrm{dL}$, high sensitivity CRP with a limit of detection of $0.15 \mathrm{mg} / \mathrm{L}$, with routine colorimetric, enzymatic, and immunoturbidimetry methods (Randox Laboratories, 55 Diamond Road, Crumlin Co. Antrim, Northern Ireland, UK), and erythrocyte sedimentation rate (ESR, $\mathrm{mm} / \mathrm{h}$ ) by Wintrobe method [37].

Through using commercial enzyme-linked immunosorbent assays (ELISA), we determined soluble levels of insulin sensitivity of $0.399 \mu \mathrm{UI} / \mathrm{mL}$ (ALPCO, 26-G Keewaydin Drive, Salem, NH 03079), sCD36 sensitivity of $312.5 \mathrm{ng} / \mathrm{mL}$, and sLOX-1 sensitivity of $5.0 \mathrm{pg} / \mathrm{mL}$ (AVISCERA BIOSCENCE, INC., 2348 Walsh Avenue, Suite C, Santa Clara, CA 95051). Based on the lipid profile measurements, we calculated the following atherogenic indexes: TC/HDLc, LDLc/HDLc, TG/HDLc, and Apo-A1/Apo-B.

2.5. CD36 mRNA Expression Analysis. Mononuclear cells from the subjects were isolated by density gradient media with separating solution Lymphoprep ${ }^{\mathrm{TM}}$ (AXIS-SHIELD, P.O. Box 6863, Rodelokka, 0504 Oslo, Norway) [38]. Purified mononuclear cells were used directly for total RNA isolation; it was performed according to the manufacturer's procedure using TRIzol ${ }^{\circledR}$ LS Reagent (Ambion, Invitrogen ${ }^{\mathrm{TM}}$, by Life Technologies, 5791 Van Allen Way, Carlsbad, CA 92008) based on the single-step RNA isolation modified method reported by Chomczynski and Sacchi $[39,40]$. The complementary DNA synthesis (cDNA) was performed with $2 \mu \mathrm{g}$ of each total RNA sample using a reaction size of $20 \mu \mathrm{L}$ with oligo (dT) 18-primer (100 ng/ $\mu \mathrm{L}$ ), RNase-free, DEPC treated water and Moloney Murine Leukemia Virus Reverse Transcriptase (M-MLV RT) kit (Applied Biosystems, 850 Lincoln Centre Drive, Foster City, CA 94404) and stored at $-20^{\circ} \mathrm{C}$ until being used for expression analyses.
Real-time quantitative polymerase chain reaction (qPCR) was conducted using the StepOne detection system, EXPRESS SYBR ${ }^{\circledR}$ GreenER $^{\mathrm{TM}}$ qPCR SuperMix Universal, and sequence detector software (Applied Biosystems, 850 Lincoln Centre Drive, Foster City, CA 94404) was used for data analysis. A threshold cycle $\left(\mathrm{C}_{\mathrm{T}}\right)$ value was determined from each amplification plot.

In brief, CD36 mRNA expression was performed in a final reaction volume of $20 \mathrm{~mL}$ ( $40 \mu \mathrm{M}$ forward and reverse primer, $50 \mathrm{nM}$ ROX, $2 \mathrm{x}$ SYBR Green qPCR master mix and cDNA $100 \mathrm{ng}$ ). The conditions of the reaction were as follows: holding at $95^{\circ} \mathrm{C} / 10 \mathrm{~min}$, cycling $\left(35\right.$ cycles of $95^{\circ} \mathrm{C} / 15 \mathrm{~s}$ and $60^{\circ} \mathrm{C} / 60 \mathrm{~s}$ ), and melt curve at $95^{\circ} \mathrm{C} / 15 \mathrm{~s}, 60^{\circ} \mathrm{C} / 60 \mathrm{~s}$, and $95^{\circ} \mathrm{C} / 15 \mathrm{~s}$. Expression of target genes was normalized by the endogenous reference gene GAPDH; sequence specific primers were forward: $5^{\prime}$-GGAGCGAGATCCCTCCAAAAT- $3^{\prime}$ [41] and reverse: $5^{\prime}$-GGCTGTTGTCATACTTCTCATGG-3' and for CD36 target gene they were forward: $5^{\prime}$ CTATGCTGTATTTGAATCCGACGTT- ${ }^{\prime}{ }^{2}$ [42] and reverse: $5^{\prime}$-CCTGTGTACATTTCACTTCCTCATT- $3^{\prime}$.

The relative expression fold changes of target genes were calculated using the comparative $C_{T}$ method with $2^{-\Delta \Delta C_{T}}$ equation [43]. For quality control, a blank and samples previously confirmed as positive for each gene were used as controls. In addition, all samples were identified in duplicate by two different analysts. The expression success rate was $100 \%$.

2.6. Statistical Analysis. Data were analyzed with statistics software SPSS v21 (IBM Inc., Chicago, IL, USA) and with GraphPad Prism v6.01 (2014 Inc., 2236 Beach Avenue, Jolla, CA 92037). Results are given as mean \pm standard deviation (SD). The data distribution of clinical and laboratory variables was evaluated with $Z$ Kolmogorov-Smirnov test; parametric and nonparametric tests were performed as appropriate. An age and gender (male or female) adjusted ANCOVA analysis was made in individuals included in the study. The clinical and laboratory characteristics of the study group were analyzed with unpaired Student's $t$-test or Mann-Whitney $U$ test to compare quantitative data in two groups. Data from serum concentrations of scavenger receptors, laboratorial assessment, and adiposity variables were subjected to Pearson's correlation tests. A two-tailed $P$ value less than 0.05 was considered statistically significant.

\section{Results}

3.1. Study Subjects Show Increased Body Fat Storage and Cardiovascular Disease Risk. We included 151 individuals that were classified by age and presence of abdominal obesity; $70 \%$ were females. The anthropometric measures are shown in Table 1. Seventy percent presented overweight (mean BMI: $29.88 \pm 3.3 \mathrm{~kg} / \mathrm{m}^{2}$ ), $37 \%$ of these individuals were categorized with CVD risk, almost $70 \%$ of the group were older than $\geq 30$ years (data no shown), and $78 \%$ were identified with an increased body fat storage.

When comparing subgroups with abdominal obesity, we observed a similar distribution of trunk fat storage in young and older individuals, while older subjects presented 
TABLE 1: Body dimensions and distribution of body fat storage according to age and abdominal obesity.

\begin{tabular}{|c|c|c|c|c|}
\hline \multirow[b]{4}{*}{$n$} & \multicolumn{4}{|c|}{ Study group } \\
\hline & \multicolumn{2}{|c|}{$<30$ years old } & \multicolumn{2}{|c|}{$\geq 30$ years old } \\
\hline & $\begin{array}{l}\text { Without abdominal } \\
\text { obesity }\end{array}$ & $\begin{array}{l}\text { With abdominal } \\
\text { obesity }\end{array}$ & $\begin{array}{l}\text { Without abdominal } \\
\text { obesity }\end{array}$ & $\begin{array}{c}\text { With abdominal } \\
\text { obesity }\end{array}$ \\
\hline & 21 & 24 & 12 & 94 \\
\hline Female (\%) & $14(67)$ & $11(45)$ & $10(83)$ & $71(75)$ \\
\hline Age (years) & $23 \pm 3$ & $24 \pm 3$ & $41 \pm 9$ & $45 \pm 8$ \\
\hline BMI $\left(\mathrm{kg} / \mathrm{m}^{2}\right)$ & $22.8 \pm 2.4$ & $28.5 \pm 3.8$ & $24.4 \pm 1.7$ & $30.0 \pm 3.3$ \\
\hline \multicolumn{5}{|l|}{ Measurements } \\
\hline Height $(\mathrm{cm})$ & $169.7 \pm 8.6$ & $170.5 \pm 9.0$ & $160.6 \pm 6.2$ & $163.2 \pm 9.1$ \\
\hline Body weight $(\mathrm{kg})^{*}$ & $65.9 \pm 9.6$ & $83.3 \pm 15.1$ & $62.9 \pm 6.0$ & $80.3 \pm 12.4$ \\
\hline Total body fat mass $(\mathrm{kg})^{*}$ & $15.2 \pm 6.2$ & $26.3 \pm 7.8$ & $19.5 \pm 4.2$ & $28.7 \pm 7.0$ \\
\hline Body fat mass $(\%)^{*}$ & $23.2 \pm 8.6$ & $31.9 \pm 8.1$ & $30.8 \pm 2.2$ & $35.6 \pm 6.8$ \\
\hline Waist circumference $(\mathrm{cm})^{*}$ & $79.7 \pm 6.9$ & $98.5 \pm 8.4$ & $79.4 \pm 4.3$ & $101.0 \pm 8.7$ \\
\hline Hip circumference $(\mathrm{cm})^{*}$ & $99.1 \pm 5.6$ & $108.4 \pm 5.9$ & $99.4 \pm 4.8$ & $109.5 \pm 7.6$ \\
\hline Trunk body fat mass $(\mathrm{kg})^{*}$ & $7.5 \pm 3.5$ & $14.5 \pm 4.1$ & $9.4 \pm 2.4$ & $14.5 \pm 3.8$ \\
\hline Trunk body fat mass $(\%)^{*}$ & $11.3 \pm 4.6$ & $17.4 \pm 3.4$ & $14.7 \pm 3.3$ & $18.0 \pm 3.5$ \\
\hline Total adipose area $\left(\mathrm{cm}^{2}\right)^{*}$ & $510 \pm 85$ & $778 \pm 135$ & $503 \pm 54$ & $817 \pm 145$ \\
\hline Subcutaneous abdominal area $\left(\mathrm{cm}^{2}\right)^{*}$ & $381 \pm 140$ & $579 \pm 185$ & $489 \pm 45$ & $604 \pm 253$ \\
\hline Visceral area $\left(\mathrm{cm}^{2}\right)$ & $301 \pm 586$ & $267 \pm 277$ & $456 \pm 769$ & $435 \pm 699$ \\
\hline Sagittal abdominal diameter $(\mathrm{cm})^{*}$ & $17.8 \pm 2.1$ & $21.7 \pm 2.6$ & $18.6 \pm 1.1$ & $23.0 \pm 3.7$ \\
\hline Coronal abdominal diameter $(\mathrm{cm})^{*}$ & $28.2 \pm 4.1$ & $33.8 \pm 4.9$ & $28.9 \pm 3.8$ & $31.5 \pm 6.7$ \\
\hline \multicolumn{5}{|l|}{ Skinfold thickness (mm) } \\
\hline Biceps & $7.8 \pm 4.5$ & $9.5 \pm 4.2$ & $9.4 \pm 4.4$ & $12.9 \pm 5.2$ \\
\hline Triceps ${ }^{*}$ & $16.0 \pm 5.1$ & $29.1 \pm 30.3$ & $17.8 \pm 4.1$ & $21.6 \pm 6.3$ \\
\hline Subscapular* & $15.2 \pm 5.3$ & $20.4 \pm 8.6$ & $17.1 \pm 5.1$ & $23.9 \pm 12.8$ \\
\hline Suprailiac $^{*}$ & $13.6 \pm 5.7$ & $19.6 \pm 8.1$ & $15.0 \pm 7.1$ & $20.8 \pm 6.7$ \\
\hline Abdominal & $18.5 \pm 7.9$ & $18.9 \pm 9.5$ & $20.5 \pm 9.2$ & $23.8 \pm 8.8$ \\
\hline ST5 ${ }^{*}$ & $70.5 \pm 25.0$ & $97.7 \pm 47.2$ & $80.0 \pm 26.0$ & $103.3 \pm 29.7$ \\
\hline
\end{tabular}

$n=151$. Data are presented as mean \pm SD. Mann-Whitney $U$ test with ${ }^{*} P<0.001$ comparing groups by age: individuals with abdominal obesity versus individuals without abdominal obesity. BMI: body mass index; ST5: sum of five measures of skinfold thicknesses (i.e., biceps, triceps, subscapular, suprailiac, and abdominal).

higher measurements on triceps, subscapular, and suprailiac skinfold thickness compared to younger subjects (Table 1).

Additionally, in the abdominal obesity subgroup, we observed increased WHtR in older $(0.619 \pm 0.054)$ versus younger $(0.574 \pm 0.042)$ individuals $(P=0.019)$.

3.2. Individuals with Abdominal Obesity Presented Subclinical Inflammatory State and Alterations of Lipids Profile. We found that individuals below 30 years of age with abdominal obesity showed alterations on basal glucose, total cholesterol, HDLc levels, and proinflammatory profile; this same scenario was seen in older individuals with similar adiposity characteristics in which a decreased level of Apo-A1 and HDLc was also found (Table 2). Those individuals with abdominal obesity, regardless of age, presented higher measurements of abdominal adiposity and atherogenic indexes (Figure 1).

3.3. Age and the Presence of Abdominal Obesity Have a Detrimental Effect on sCD36 and sLOX-1 Levels and Increase of Metabolic Markers. The subgroup of individuals below 30 years of age compared with the subgroup of individuals over 30 years of age showed an increase in accumulation of abdominal fat deposits in association with a dyslipidemic profile, which was in accordance with an increase in atherogenic indexes and metabolic markers (Figures 1(a) and 1(c) and Table 2).

We observed that individuals over 30 years of age with abdominal obesity presented lower sCD36 levels compared to individuals without abdominal obesity, while individuals aged below 30 years showed higher levels (Figure 2(a)). On the other hand, levels of sLOX-1 were lower in both groups (Figure 2(b)). A more detailed analysis was performed, in which $21 \%(\beta=67,802.625 ; P=0.001)$ of sCD36 levels are affected by sex, and $35 \%(\beta=-3,891.21 ; P=0.006)$ are affected by the combination of sex and abdominal skinfold thickness on an age adjusted ANCOVA.

3.4. CD36 Relative Expression Is Associated with Abdominal Obesity. We observed in young individuals with abdominal obesity a slight increase in relative expression (1.11 fold times versus individuals without abdominal obesity); on the other hand, the group over 30 years of age with abdominal obesity showed subexpression (54\% less, Figure 2(c)). 
TABLE 2: Metabolic and inflammation markers in individuals included in the study.

\begin{tabular}{|c|c|c|c|c|}
\hline \multirow{3}{*}{ Measurements } & \multicolumn{4}{|c|}{ Study group } \\
\hline & \multicolumn{2}{|c|}{$<30$ years old } & \multicolumn{2}{|c|}{$\geq 30$ years old } \\
\hline & $\begin{array}{l}\text { Without abdominal } \\
\text { obesity }\end{array}$ & $\begin{array}{l}\text { With abdominal } \\
\text { obesity }\end{array}$ & $\begin{array}{l}\text { Without abdominal } \\
\text { obesity }\end{array}$ & $\begin{array}{l}\text { With abdominal } \\
\text { obesity }\end{array}$ \\
\hline$n$ & 21 & 24 & 12 & 94 \\
\hline Basal glucose $(\mathrm{mg} / \mathrm{dL})^{*}$ & $86 \pm 12$ & $97 \pm 15$ & $88 \pm 9$ & $98 \pm 13$ \\
\hline Basal insulin $(\mu \mathrm{UI} / \mathrm{mL})$ & $13.5 \pm 9.8$ & $18.7 \pm 10.6$ & $17.5 \pm 12.8$ & $16.1 \pm 15.0$ \\
\hline Triglycerides (mg/dL) & $90 \pm 41$ & $122 \pm 65$ & $120 \pm 55$ & $146 \pm 76$ \\
\hline Total cholesterol $(\mathrm{mg} / \mathrm{dL})^{*}$ & $166 \pm 30$ & $191 \pm 38$ & $235 \pm 53$ & $206 \pm 40$ \\
\hline $\operatorname{HDLc}(\mathrm{mg} / \mathrm{dL})^{*}$ & $49.0 \pm 6.6$ & $42.7 \pm 6.3$ & $51.8 \pm 4.5$ & $46.2 \pm 7.3$ \\
\hline $\operatorname{LDLc}(\mathrm{mg} / \mathrm{dL})$ & $89.4 \pm 34.5$ & $101.4 \pm 33.2$ & $126.1 \pm 36.4$ & $119.1 \pm 37.3$ \\
\hline $\operatorname{VLDLc}(\mathrm{mg} / \mathrm{dL})$ & $18.0 \pm 8.3$ & $24.4 \pm 13.1$ & $24.0 \pm 11.0$ & $29.2 \pm 15.2$ \\
\hline Apo-A1 (mg/dL)* & $137.2 \pm 46.0$ & $123.5 \pm 35.4$ & $182.1 \pm 40.3$ & $143.6 \pm 35.7$ \\
\hline Apo-B $(\mathrm{mg} / \mathrm{dL})^{*}$ & $80.0 \pm 31.1$ & $120.5 \pm 47.5$ & $127.2 \pm 51.1$ & $149.8 \pm 89.5$ \\
\hline FFA $(\mathrm{mmol} / \mathrm{mL})$ & $2.5 \pm 1.0$ & $3.1 \pm 2.2$ & $3.1 \pm 2.3$ & $3.1 \pm 1.9$ \\
\hline $\mathrm{CRP}(\mathrm{mg} / \mathrm{L})^{*}$ & $4.47 \pm 2.11$ & $6.83 \pm 3.52$ & $6.29 \pm 3.83$ & $7.4 \pm 3.7$ \\
\hline $\mathrm{C} 3(\mathrm{mg} / \mathrm{dL})^{*}$ & $110 \pm 30$ & $137 \pm 38$ & $116 \pm 25$ & $135 \pm 26$ \\
\hline $\operatorname{ESR}(\mathrm{mm} / \mathrm{h})$ & $6 \pm 4$ & $10 \pm 7$ & $12 \pm 8$ & $12 \pm 5$ \\
\hline
\end{tabular}

$n=151$. Data are presented as mean \pm SD. ${ }^{*}$ Mann-Whitney $U$ test with $P<0.05$ comparing the groups by age: individuals with abdominal obesity versus individuals without abdominal obesity. HDLc, LDLc, and VLDLc: high density lipoprotein cholesterol, low density lipoprotein cholesterol, and very low density lipoprotein cholesterol, respectively; Apo: apolipoprotein; CRP: C reactive protein; FFA: free fatty acids; ESR: erythrocyte sedimentation rate.

3.5. Adiposity Is Associated with Scavenger Receptors Levels, Low-Grade Systemic Inflammatory Markers, and Body Fat Storage Indexes. In the case of sLOX-1 and FFA levels, a positive correlation with sCD36 was observed, in contrast with the negative correlations in both scavenger receptors with abdominal adiposity and body fat mass distribution and inflammatory and metabolic markers which are displayed in Table 3.

\section{Discussion}

Abdominal obesity is generated when there is excess accumulation of adipose tissue in a progressive manner, preferably in the central region of the body. In this setting, we evaluated scavenger receptors production with metabolic, inflammatory, and adiposity profiles in two groups of adults without clinical manifestations of disease. We found a significant percent of individuals with high risk of CVD associated with the presence of abdominal obesity [44]. Although BMI is a useful tool to identify individuals at risk, there are other criteria that help recognize earlier CVD risk in an ageindependent manner $[22,23]$.

In the context of this study, clinical and anthropometric profile in individuals below 30 years of age versus individuals over 30 years of age suggests that abdominal obesity is independent of aging, which involves different phenotypes observed in several clinical stages during development of the pathogenic process.

In our study, all individuals with abdominal obesity showed increased adiposity indexes and low-grade inflammation status with dyslipidemic profile. It has been reported that accumulation of fat mass in abdominal area presents diverse subclinical alterations characterized by changes on lipid and carbohydrate metabolism [25, 45]. All these changes are due to the development of low-grade inflammation. This process starts an abnormal mechanism with the following sequential steps: the monocytes from the bloodstream migrate to adipose tissue; these cells polarize to M1 macrophages and secrete proinflammatory cytokines that can act locally in paracrine way favoring the low-grade inflammation, which is redundantly perpetuated $[20,45]$.

Although age is an important factor in the development of metabolic alterations, a remarkable observation is that, in presence of abdominal obesity, our younger group presented high atherogenic indexes compared to its corresponding older group.

We also noticed that the accumulation of abdominal fat leads to higher fasting glucose and dyslipidemia observed in individuals with abdominal obesity. These evidences confirm that the abdominal obesity can be a modifiable cardiovascular risk factor, unlike other metabolic diseases such as atherosclerosis, hypertension, and T2DM [46].

Soluble CD36 levels have been reported not only in patients with carotid stenosis and unstable atheromatous plaque but also in chronic inflammatory related states such as diabetic nephropathy, polycystic ovary syndrome, and severity of hepatic steatosis and insulin resistance and individuals with morbid obesity [47-50].

In our study we observed in individuals below 30 years of age increased levels of sCD36 in parallel with body fat deposits predominately on abdominal area. These results contrast with the opposite case observed in older individuals, where sCD36 levels decreases with age and presence of abdominal obesity. A consistent elevation of sCD36 in 

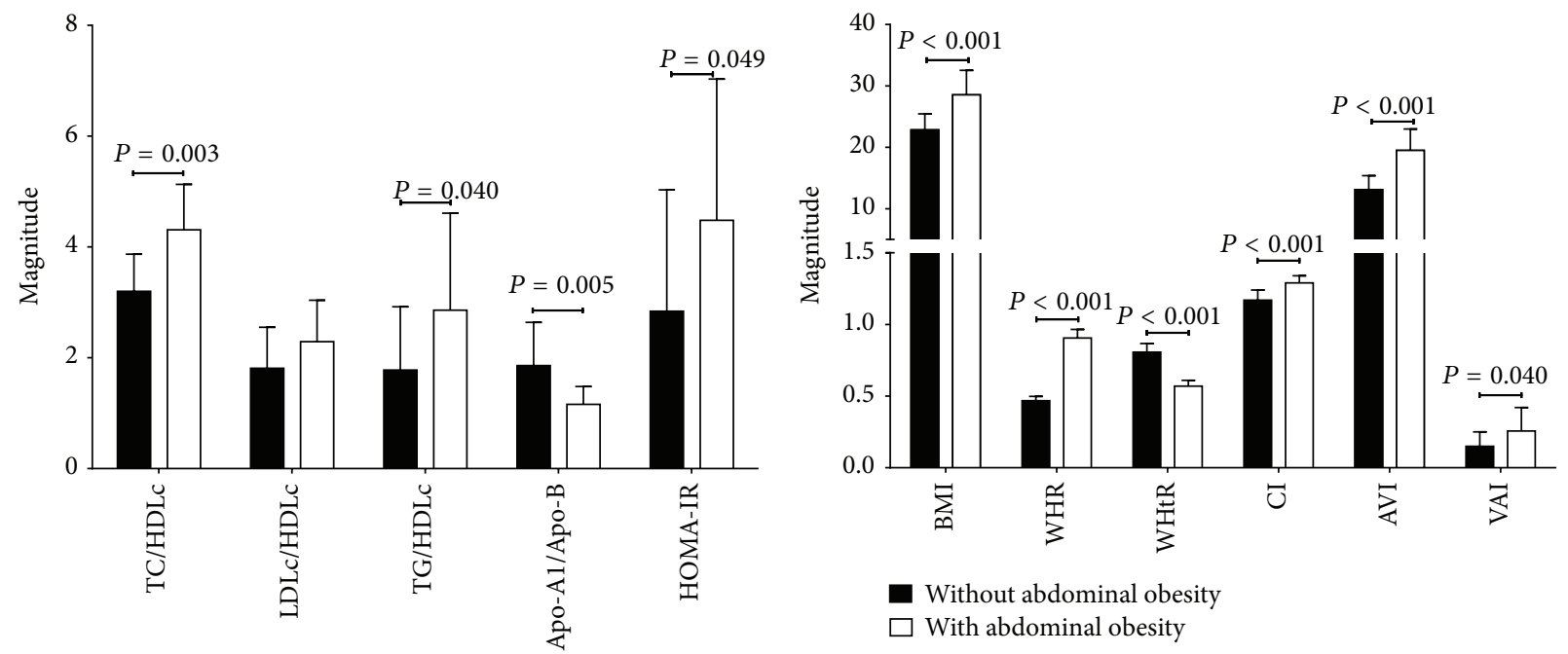

Without abdominal obesity $\square$ With abdominal obesity

(a)

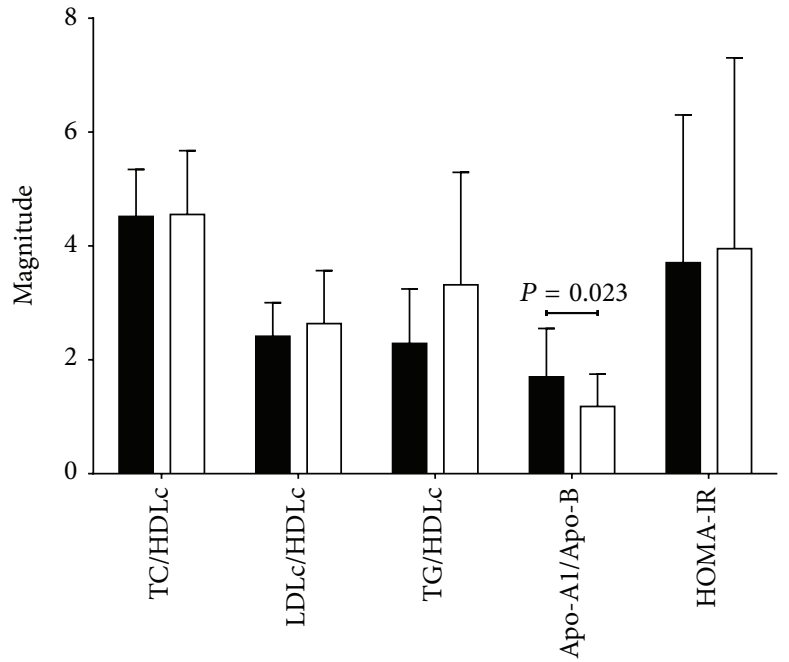

(b)

Without abdominal obesity

With abdominal obesity

(c)

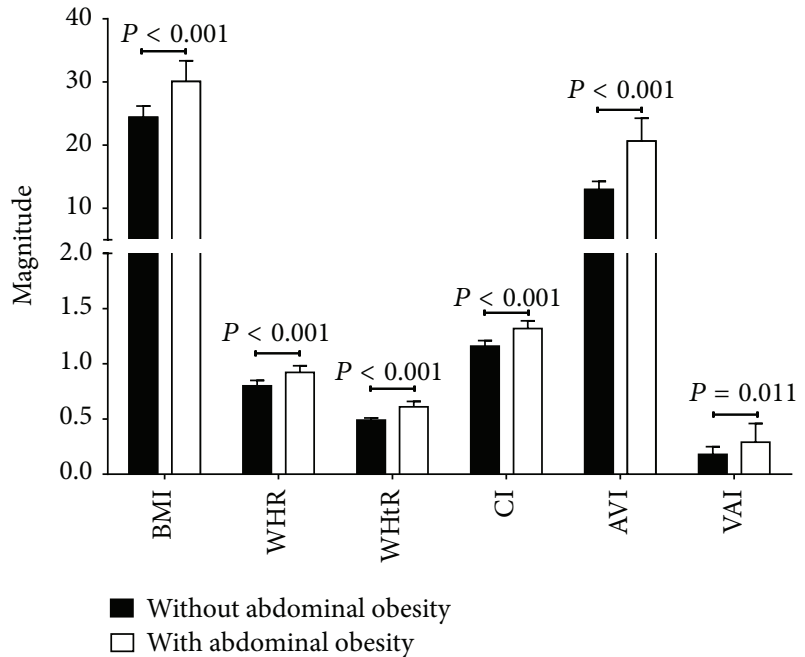

(d)

FIGURE 1: Metabolic and adiposity indexes in study group. Subjects without abdominal obesity: $n=33$; subjects with abdominal obesity: $n=$ 118. Data are presented as mean \pm SD. (a) and (b) Individuals $<30$ years old: Mann-Whitney $U$ test comparing the groups with abdominal obesity versus individuals without abdominal obesity. (c) and (d) Individuals $\geq 30$ years old with abdominal obesity versus individuals without abdominal obesity. TC: total cholesterol; HDLc, LDLc, and VLDLc: high density lipoprotein cholesterol, low density lipoprotein cholesterol, and very low density lipoprotein cholesterol, respectively; Apo: apolipoprotein; HOMA-IR: homeostasis model assessment-insulin resistance; BMI: body mass index; BFR: body fat ratio; WHtR: waist-to-height ratio; CI: conicity index; AVI: abdominal volume index; VAI: visceral adipose index.

patients with $\mathrm{T} 2 \mathrm{DM}$, insulin resistance, and obesity has been documented; after bariatric surgery in adults, sCD36 levels decline and metabolic markers improve $[8,10,14]$; meanwhile, there are reports of low receptor membrane expression on peripheral blood mononuclear cells in women with obesity and pharmacologically treated rheumatoid arthritis patients with subclinical atherosclerosis $[51,52]$. Based on these reports, we decided to measure scavenger receptor levels in individuals with abdominal obesity.

Our results showed two subsets of CD36 expression in soluble levels related to age below and above 30 years, while a low soluble LOX-1 pattern in older individuals with abdominal adiposity negative correlates with several adiposity indexes. On the contrary, we observed positive 


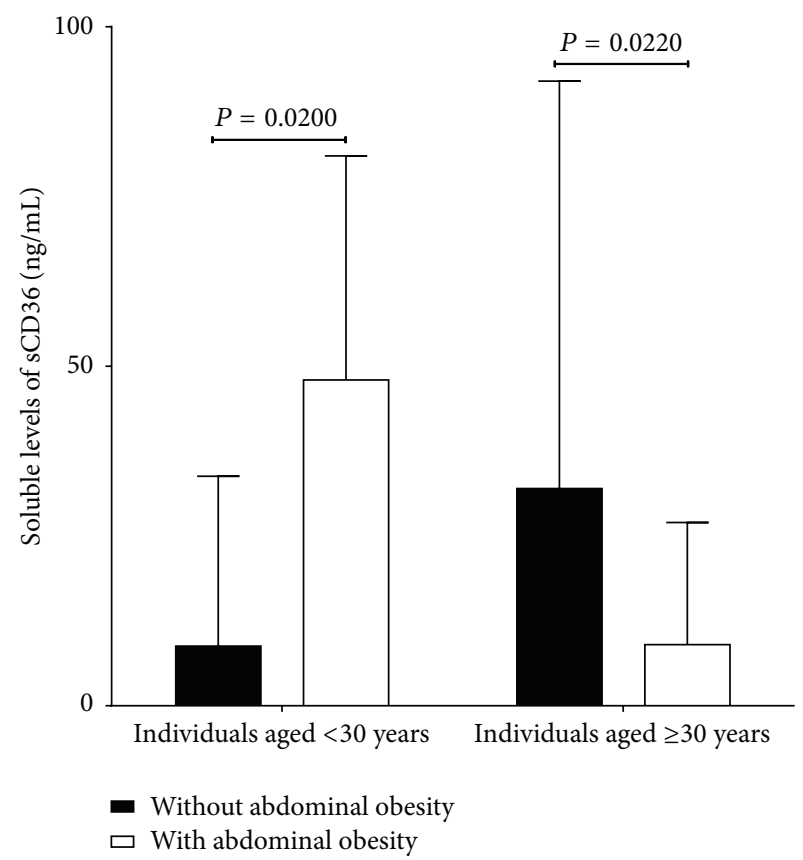

(a)

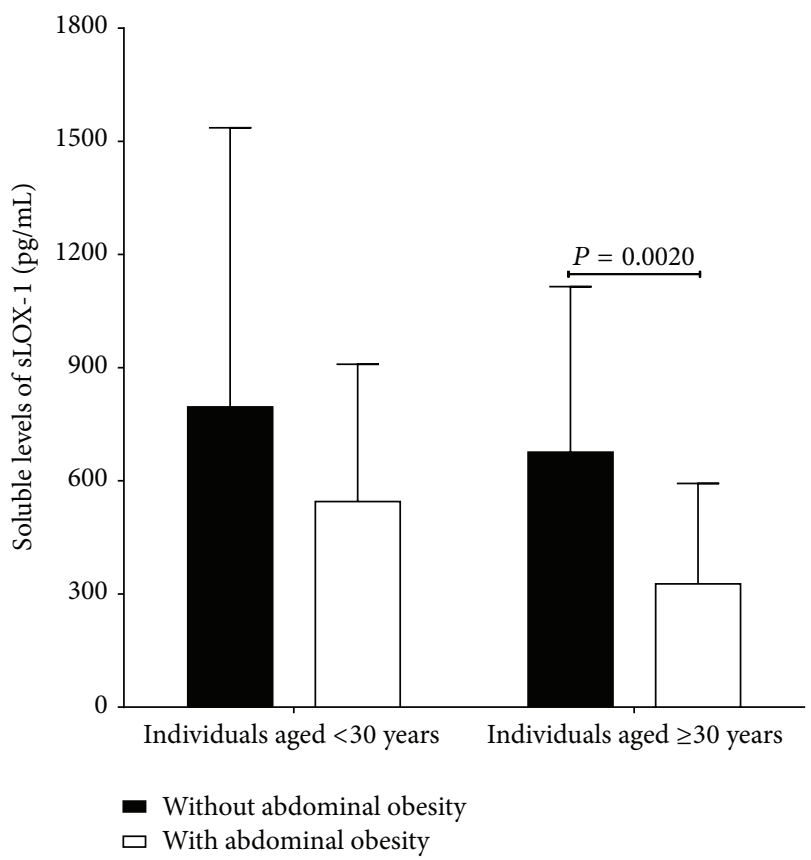

(b)

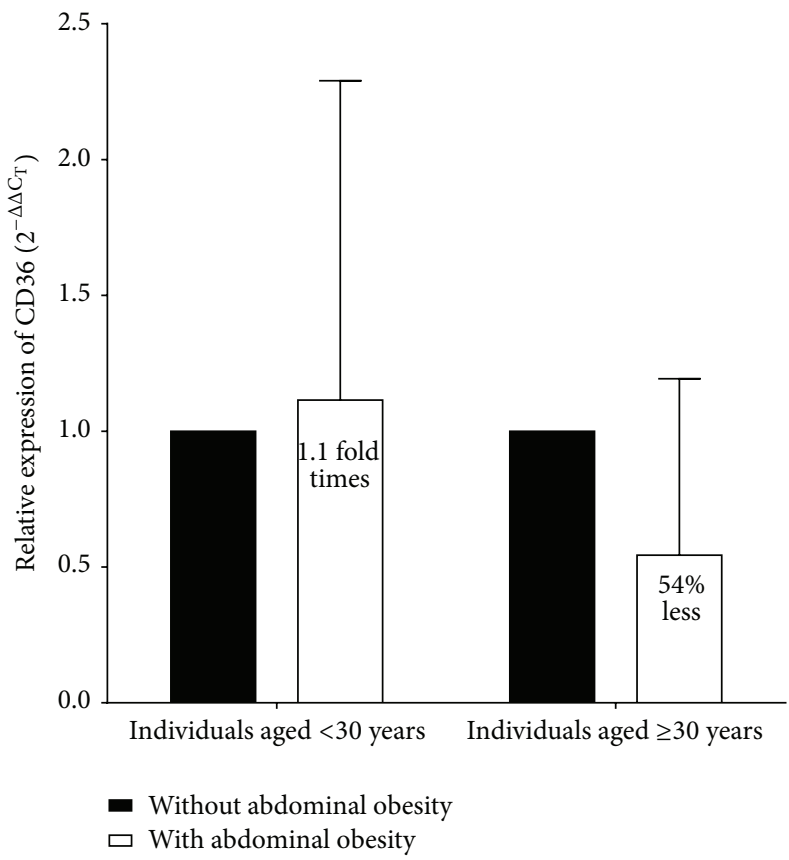

(c)

FIGURE 2: Scavenger receptors LOX-1 and sCD36 expression levels in study group. Subjects without abdominal obesity: $n=86$; subjects with abdominal obesity: $n=54$. Data are presented as mean \pm SD in individuals below 30 years of age and individuals above 30 years of age. (a) Soluble levels of CD36. (b) Soluble levels of LOX-1. (c) mRNA expression levels of CD36. LOX-1: lectin like oxidized low density lipoprotein receptor 1 .

correlations between FFA and sLOX-1 levels with sCD36 which suggest the interaction of these scavenger receptors in states of pathological adipose tissue distribution.

Increased sLOX-1 levels have been associated with acute coronary syndrome or T2DM patients that denote their contribution in atherosclerosis development [53-55]. In our study we showed an alternative scenario to what is reported in previous studies in subjects with metabolic diseases; our findings could be explained in part by a strict compliance on the inclusion criteria used in our study and by taking into account abdominal obesity indicators. Even though there is a functional redundancy in scavenger receptors it seems that in 
TABLE 3: Correlation of adiposity with scavenger receptors markers and systemic low-grade inflammatory state along body fat storage.

\begin{tabular}{|c|c|c|c|c|}
\hline \multirow{2}{*}{ Measurements } & \multicolumn{4}{|c|}{ Pearson's correlation test } \\
\hline & sCD36 & $P$ & LOX-1 & $P$ \\
\hline LOX-1 (pg/mL) & 0.249 & 0.042 & - & - \\
\hline Body mass index (BMI) & 0.359 & 0.003 & -0.359 & 0.027 \\
\hline Waist circumference $(\mathrm{cm})$ & -0.285 & 0.008 & -0.276 & 0.025 \\
\hline Hip circumference $(\mathrm{cm})$ & -0.217 & 0.045 & -0.188 & NS \\
\hline Total body fat mass (\%) & -0.334 & 0.020 & -0.221 & NS \\
\hline Trunk body fat mass (kg) & -0.229 & 0.036 & -0.225 & NS \\
\hline Total adipose area $\left(\mathrm{cm}^{2}\right)$ & -0.280 & 0.009 & -0.262 & 0.034 \\
\hline Visceral area $\left(\mathrm{cm}^{2}\right)$ & -0.282 & 0.009 & -0.251 & 0.042 \\
\hline Sagittal diameter $(\mathrm{cm})$ & -0.265 & 0.014 & -0.261 & 0.033 \\
\hline Body fat index & -0.301 & 0.038 & -0.612 & 0.001 \\
\hline Waist-to-height ratio (WHtR) & -0.313 & 0.004 & -0.378 & 0.019 \\
\hline Conicity index & -0.256 & 0.019 & -0.371 & 0.022 \\
\hline \multicolumn{5}{|l|}{ Skinfold thickness (mm) } \\
\hline Bicipital & -0.283 & 0.008 & -0.255 & 0.037 \\
\hline Subscapular & -0.308 & 0.004 & -0.235 & NS \\
\hline Suprailiac & -0.305 & 0.004 & -0.251 & 0.040 \\
\hline Abdominal & -0.325 & 0.002 & -0.258 & 0.036 \\
\hline ST5 (mm) & -0.257 & 0.017 & -0.245 & 0.048 \\
\hline Basal glucose (mg/dL) & -0.189 & NS & -0.258 & 0.038 \\
\hline Total cholesterol (mg/dL) & -0.255 & 0.017 & 0.001 & NS \\
\hline HDLc (mg/dL) & -0.292 & 0.044 & 0.089 & NS \\
\hline LDLc (mg/dL) & -0.247 & 0.021 & -0.027 & NS \\
\hline VLDLc (mg/dL) & -0.379 & 0.009 & -0.406 & 0.013 \\
\hline LDLc/HDLc & -0.251 & 0.019 & -0.053 & NS \\
\hline Apo-A1 (mg/L) & 0.463 & 0.001 & -0.383 & 0.018 \\
\hline Apo-A1/Apo-B & -0.225 & 0.039 & -0.048 & NS \\
\hline $\mathrm{FFA}(\mathrm{mmol} / \mathrm{mL})$ & 0.377 & 0.020 & 0.167 & NS \\
\hline $\mathrm{CRP}(\mathrm{mg} / \mathrm{L})$ & -0.325 & 0.002 & -0.072 & NS \\
\hline C3 (mg/dL) & -0.324 & 0.024 & -0.431 & 0.007 \\
\hline $\operatorname{ESR}(\mathrm{mm} / \mathrm{h})$ & -0.107 & NS & -0.396 & 0.014 \\
\hline
\end{tabular}

$n=151$. HDLc, LDLc, and VLDLc: high density lipoprotein cholesterol, low density lipoprotein cholesterol, and very low density lipoprotein cholesterol, respectively; Apo: apolipoprotein; CRP: C reactive protein; FFA: free fatty acids; ESR: erythrocyte sedimentation rate.

undefined circumstances they work as coreceptors to display several responses in different clinical context; this interplay between receptors has not been completely elucidated [56].

While CD36 soluble receptor levels are considered an early marker of insulin resistance, it could also be considered that modulation of scavenger receptor could represent a precompensation mechanism in individuals with an altered metabolism. Based on our results, we could hypothesize that low soluble CD36 levels and their gene subexpression may be an early homeostatic state previous to the establishment of metabolic syndrome, thereby reinforcing the central role of dysfunctional adipose tissue as a trigger for the metabolic complications associated with long-term obesity. The multiple functions and the heterogeneity of cells that express this receptor make it difficult to isolate the exact role of these receptors in diverse clinical contexts.

\section{Conclusions}

In this study, individuals over 30 years of age presented low soluble scavenger receptors levels pattern and CD36 gene subexpression, which suggest the chronic metabolic dysregulation in abdominal adiposity.

\section{Competing Interests}

The authors declare that there are no competing interests regarding the publication of this paper.

\section{Acknowledgments}

This work was supported by Grant no. 220214 to UDGCA-701: Academic group "Aging, Immuno-metabolism and Oxidative Stress."

\section{References}

[1] World Health Organization, Obesity: Preventing and Managing the Global Epidemic. Report of a WHO Consultation, WHO, 2000.

[2] J. M. Crow, "Obesity: insensitive issue," Nature, vol. 486, no. 7403, pp. S12-S13, 2012.

[3] J. P. Despres, I. Lemieux, J. Bergeron et al., "Abdominal obesity and the metabolic syndrome: contribution to global cardiometabolic risk," Arteriosclerosis, Thrombosis, and Vascular Biology, vol. 28, no. 6, pp. 1039-1049, 2008.

[4] S. Collot-Teixeira, J. Martin, C. McDermott-Roe, R. Poston, and J. L. McGregor, "CD36 and macrophages in atherosclerosis," Cardiovascular Research, vol. 75, no. 3, pp. 468-477, 2007.

[5] R. Yoshimoto, Y. Fujita, A. Kakino, S. Iwamoto, T. Takaya, and T. Sawamura, "The discovery of LOX-1, its ligands and clinical significance," Cardiovascular Drugs and Therapy, vol. 25, no. 5, pp. 379-391, 2011.

[6] M. Piechota, A. Banaszewska, J. Dudziak, M. Slomczynski, and R. Plewa, "Highly upregulated expression of CD36 and MSR1 in circulating monocytes of patients with acute coronary syndromes," Protein Journal, vol. 31, no. 6, pp. 511-518, 2012.

[7] N. Rasouli, A. Yao-Borengasser, V. Varma et al., "Association of scavenger receptors in adipose tissue with insulin resistance in nondiabetic humans," Arteriosclerosis, Thrombosis, and Vascular Biology, vol. 29, no. 9, pp. 1328-1335, 2009.

[8] L. Knøsgaard, S. B. Thomsen, M. Støckel, H. Vestergaard, and A. Handberg, "Circulating sCD36 is associated with unhealthy fat distribution and elevated circulating triglycerides in morbidly obese individuals," Nutrition and Diabetes, vol. 4, article el14, 2014.

[9] A. Tuten, B. Aydemir, M. Oncul et al., "The association of lectinlike oxidized LDL receptor 1 (LOX-1) K167N and 3'UTR188CT polymorphisms with maternal plasma soluble LOX-1 levels and preeclampsia risk in Turkish population," Archives of Gynecology and Obstetrics, vol. 291, no. 3, pp. 563-571, 2015.

[10] A. Handberg, K. Levin, K. Højlund, and H. Beck-Nielsen, "Identification of the oxidized low-density lipoprotein scavenger receptor CD36 in plasma: a novel marker of insulin resistance," Circulation, vol. 114, no. 11, pp. 1169-1176, 2006.

[11] A. Handberg, A. López-Bermejo, J. Bassols, J. Vendrell, W. Ricart, and J. M. Fernández-Real, "Circulating soluble CD36 
is associated with glucose metabolism and interleukin-6 in glucose-intolerant men," Diabetes and Vascular Disease Research, vol. 6, no. 1, pp. 15-20, 2009.

[12] M. Balin, A. Celik, and M. A. Kobat, "The association between soluble lectin-like oxidized low-density lipoprotein receptor-1 levels and patients with isolated coronary artery ectasia," Journal of Thrombosis and Thrombolysis, vol. 33, no. 3, pp. 239-245, 2012.

[13] M. Balin, A. Çelik, M. A. Kobat, and A. Baydas, "Circulating soluble lectin-like oxidized low-density lipoprotein receptor1 levels predict percutaneous coronary intervention-related periprocedural myocardial infarction in stable patients undergoing elective native single-vessel PCI," Journal of Thrombosis and Thrombolysis, vol. 34, no. 4, pp. 483-490, 2012.

[14] A. Handberg, M. Norberg, H. Stenlund, G. Hallmans, J. Attermann, and J. W. Eriksson, "Soluble CD36 (sCD36) clusters with markers of insulin resistance, and high sCD36 is associated with increased type 2 diabetes risk," Journal of Clinical Endocrinology and Metabolism, vol. 95, no. 4, pp. 1939-1945, 2010.

[15] T. E. Brinkley, N. Kume, H. Mitsuoka, D. A. Phares, and J. M. Hagberg, "Elevated soluble lectin-like oxidized LDL receptor-1 (sLOX-1) levels in obese postmenopausal women," Obesity, vol. 16, no. 6, pp. 1454-1456, 2008.

[16] T. Otsuki, S. Maeda, J. Mukai, M. Ohki, M. Nakanishi, and T. Yoshikawa, "Association between plasma sLOX-1 concentration and arterial stiffness in middle-aged and older individuals," Journal of Clinical Biochemistry and Nutrition, vol. 57, no. 2, pp. 151-155, 2015.

[17] M. Fukui, M. Tanaka, T. Senmaru et al., "LOX-1 is a novel marker for peripheral artery disease in patients with type 2 diabetes," Metabolism, vol. 62, no. 7, pp. 935-938, 2013.

[18] Y. Nomata, N. Kume, H. Sasai et al., "Weight reduction can decrease circulating soluble lectin-like oxidized low-density lipoprotein receptor-1 levels in overweight middle-aged men," Metabolism: Clinical and Experimental, vol. 58, no. 9, pp. 12091214, 2009.

[19] A. Chawla, K. D. Nguyen, and Y. P. S. Goh, "Macrophagemediated inflammation in metabolic disease," Nature Reviews Immunology, vol. 11, no. 11, pp. 738-749, 2011.

[20] D. J. Kennedy, S. Kuchibhotla, K. M. Westfall, R. L. Silverstein, R. E. Morton, and M. Febbraio, "A CD36-dependent pathway enhances macrophage and adipose tissue inflammation and impairs insulin signalling," Cardiovascular Research, vol. 89, no. 3, pp. 604-613, 2011.

[21] A. Berber, R. Gómez-Santos, G. Fanghänel, and L. SánchezReyes, "Anthropometric indexes in the prediction of type 2 diabetes mellitus, hypertension and dyslipidaemia in a Mexican population," International Journal of Obesity, vol. 25, no. 12, pp. 1794-1799, 2001.

[22] S. R. Millar, I. J. Perry, and C. M. Phillips, "Assessing cardiometabolic risk in middle-aged adults using body mass index and waist-height ratio: are two indices better than one? A crosssectional study," Diabetology and Metabolic Syndrome, vol. 7, no. 1, article 73, 2015.

[23] C. Nishida, G. T. Ko, and S. Kumanyika, "Body fat distribution and noncommunicable diseases in populations: overview of the 2008 WHO Expert Consultation on Waist Circumference and Waist-Hip Ratio," European Journal of Clinical Nutrition, vol. 64, no. 1, pp. 2-5, 2010.

[24] (WHO) and C.f.I.O.o.M.S.C.i.c.w.t.W.H.O, International Ethical Guidelines for Biomedical Research Involving Human Subjects, 2002.
[25] H. S. Kahn, "Choosing an index for abdominal obesity: an opportunity for epidemiologic clarification," Journal of Clinical Epidemiology, vol. 46, no. 5, pp. 491-494, 1993.

[26] M. Garaulet, J. J. Hernández-Morante, F. J. Tébar, S. Zamora, and M. Canteras, "Two-dimensional predictive equation to classify visceral obesity in clinical practice," Obesity, vol. 14, no. 7, pp. 1181-1191, 2006.

[27] H. S. Kahn, Q. Gu, K. M. Bullard, D. S. Freedman, N. Ahluwalia, and C. L. Ogden, "Population distribution of the sagittal abdominal diameter (SAD) from a representative sample of US adults: comparison of SAD, waist circumference and body mass index for identifying dysglycemia," PLoS ONE, vol. 9, no. 10, Article ID e108707, 2014.

[28] P. Pajunen, H. Rissanen, M. A. Laaksonen, M. Heliövaara, A. Reunanen, and P. Knekt, "Sagittal abdominal diameter as a new predictor for incident diabetes," Diabetes Care, vol. 36, no. 2, pp. 283-288, 2013.

[29] World Health Organization, Waist Circumference and WaistHip Ratio: Report of a WHO Expert Consultation, World Health Organization, Geneva, Switzerland, 2008.

[30] (NHANES), N.H.a.N.E.S. Antropometry Procedures Manual, 2013.

[31] R. Ness-Abramof and C. M. Apovian, "Waist circumference measurement in clinical practice," Nutrition in Clinical Practice, vol. 23, no. 4, pp. 397-404, 2008.

[32] M. C. Amato, C. Giordano, M. Galia et al., "Visceral Adiposity Index: a reliable indicator of visceral fat function associated with cardiometabolic risk," Diabetes Care, vol. 33, no. 4, pp. 920-922, 2010.

[33] D. R. Matthews, J. P. Hosker, A. S. Rudenski, B. A. Naylor, D. F. Treacher, and R. C. Turner, "Homeostasis model assessment: insulin resistance and $\beta$-cell function from fasting plasma glucose and insulin concentrations in man," Diabetologia, vol. 28, no. 7, pp. 412-419, 1985.

[34] T. M. Wallace and D. R. Matthews, "The assessment of insulin resistance in man," Diabetic Medicine, vol. 19, no. 7, pp. 527-534, 2002.

[35] F.-I. Corona-Meraz, R.-E. Navarro-Hernández, S.-L. RuízQuezada et al., "Inverse relationship of the CMKLR1 relative expression and chemerin serum levels in obesity with dysmetabolic phenotype and insulin resistance," Mediators of Inflammation, vol. 2016, Article ID 3085390, 9 pages, 2016.

[36] W. T. Friedewald, R. I. Levy, and D. S. Fredrickson, "Estimation of the concentration of low-density lipoprotein cholesterol in plasma, without use of the preparative ultracentrifuge," Clinical Chemistry, vol. 18, no. 6, pp. 499-502, 1972.

[37] M. M. Wintrobe and J. W. Landsberg, "A standardized technique for the blood sedimentation test. 1935," The American Journal of the Medical Sciences, vol. 346, no. 2, pp. 148-153, 2013.

[38] A. Böyum, "Separation of leukocytes from blood and bone marrow. Introduction," Scandinavian Journal of Clinical and Laboratory Investigation. Supplementum, vol. 97, article 7, 1968.

[39] P. Chomczynski, "A reagent for the single-step simultaneous isolation of RNA, DNA and proteins from cell and tissue samples," BioTechniques, vol. 15, no. 3, pp. 532-537, 1993.

[40] P. Chomczynski and N. Sacchi, "Single-step method of RNA isolation by acid guanidinium thiocyanate-phenol-chloroform extraction," Analytical Biochemistry, vol. 162, no. 1, pp. 156-159, 1987.

[41] Q. Tang, W. Wu, X. Xu et al., "miR-141 contributes to fetal growth restriction by regulating PLAG1 expression," PLOS ONE, vol. 8, no. 3, Article ID e58737, 2013. 
[42] A. Das, T. K. Das, U. Sahu, B. P. Das, S. K. Kar, and M. R. Ranjit, "CD36 T188G gene polymorphism and severe falciparum malaria in India," Transactions of the Royal Society of Tropical Medicine and Hygiene, vol. 103, no. 7, pp. 687-690, 2009.

[43] K. J. Livak and T. D. Schmittgen, "Analysis of relative gene expression data using real-time quantitative PCR and the 2$\Delta \Delta$ CT method," Methods, vol. 25, no. 4, pp. 402-408, 2001.

[44] J.-P. Després and I. Lemieux, "Abdominal obesity and metabolic syndrome," Nature, vol. 444, no. 7121, pp. 881-887, 2006.

[45] A. Tchernof and J.-P. Després, "Pathophysiology of human visceral obesity: an update," Physiological Reviews, vol. 93, no. 1, pp. 359-404, 2013.

[46] K. C. Zalesin, B. A. Franklin, W. M. Miller, E. D. Peterson, and P. A. McCullough, "Impact of obesity on cardiovascular disease," Endocrinology Metabolism Clinics of North America, vol. 37, no. 3, pp. 663-684, 2008.

[47] T. M. Shiju, V. Mohan, M. Balasubramanyam, and P. Viswanathan, "Soluble CD36 in plasma and urine: a plausible prognostic marker for diabetic nephropathy," Journal of Diabetes and its Complications, vol. 29, no. 3, pp. 400-406, 2015.

[48] D. Glintborg, K. Højlund, M. Andersen, J. E. Henriksen, H. Beck-Nielsen, and A. Handberg, "Soluble CD36 and risk markers of insulin resistance and atherosclerosis are elevated in polycystic ovary syndrome and significantly reduced during pioglitazone treatment," Diabetes Care, vol. 31, no. 2, pp. 328$334,2008$.

[49] C. García-Monzón, O. Lo Iacono, J. Crespo et al., "Increased soluble CD36 is linked to advanced steatosis in nonalcoholic fatty liver disease," European Journal of Clinical Investigation, vol. 44, no. 1, pp. 65-73, 2014.

[50] J.-M. Fernández-Real, A. Handberg, F. Ortega, K. Højlund, J. Vendrell, and W. Ricart, "Circulating soluble CD36 is a novel marker of liver injury in subjects with altered glucose tolerance," Journal of Nutritional Biochemistry, vol. 20, no. 6, pp. 477-484, 2009.

[51] J. Kuliczkowska-Płaksej, G. Bednarek-Tupikowska, and A. Filus, "Receptor CD36 expression on peripheral blood monocytes in women with visceral obesity," Endokrynologia Polska, vol. 59, no. 6, pp. 483-489, 2008.

[52] E. Gómez-Bañuelos, B. T. Martín-Márquez, E. A. MartínezGarcía et al., "Low levels of CD36 in peripheral blood monocytes in subclinical atherosclerosis in rheumatoid arthritis: a cross-sectional study in a Mexican population," BioMed Research International, vol. 2014, Article ID 736786, 6 pages, 2014.

[53] K. C. B. Tan, S. W. M. Shiu, Y. Wong, L. Leng, and R. Bucala, "Soluble lectin-like oxidized low density lipoprotein receptor-1 in type 2 diabetes mellitus," Journal of Lipid Research, vol. 49, no. 7, pp. 1438-1444, 2008.

[54] K. Hayashida, N. Kume, T. Murase et al., "Serum soluble lectin-like oxidized low-density lipoprotein receptor-1 levels are elevated in acute coronary syndrome a novel marker for early diagnosis," Circulation, vol. 112, no. 6, pp. 812-818, 2005.

[55] T. Murase, N. Kume, H. Kataoka et al., "Identification of soluble forms of lectin-like oxidized LDL receptor-1," Arteriosclerosis, Thrombosis, and Vascular Biology, vol. 20, no. 3, pp. 715-720, 2000.

[56] J. Canton, D. Neculai, and S. Grinstein, "Scavenger receptors in homeostasis and immunity," Nature Reviews Immunology, vol. 13, no. 9, pp. 621-634, 2013. 


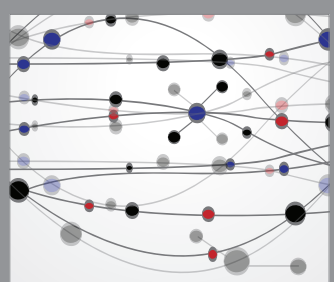

The Scientific World Journal
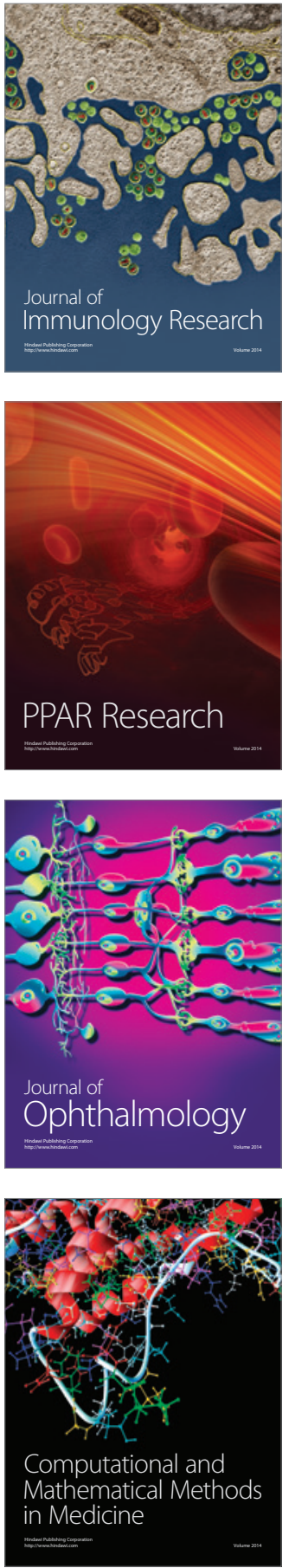

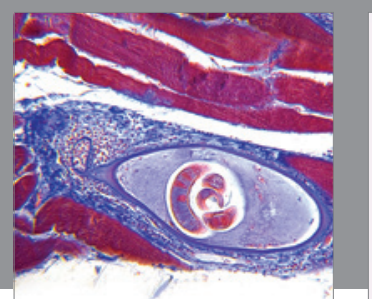

Gastroenterology Research and Practice

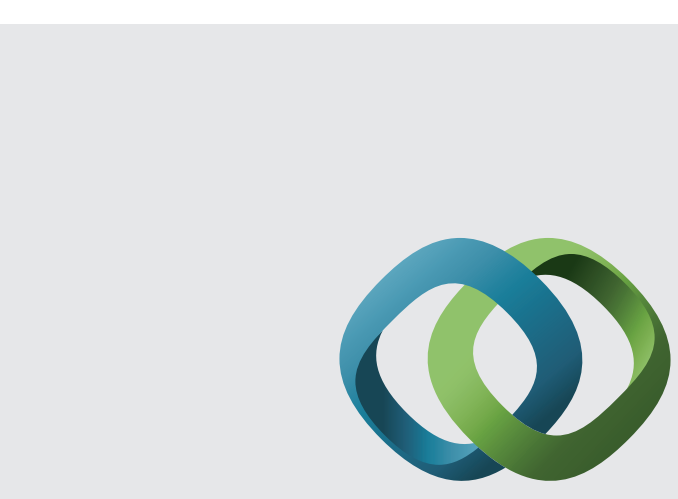

\section{Hindawi}

Submit your manuscripts at

http://www.hindawi.com
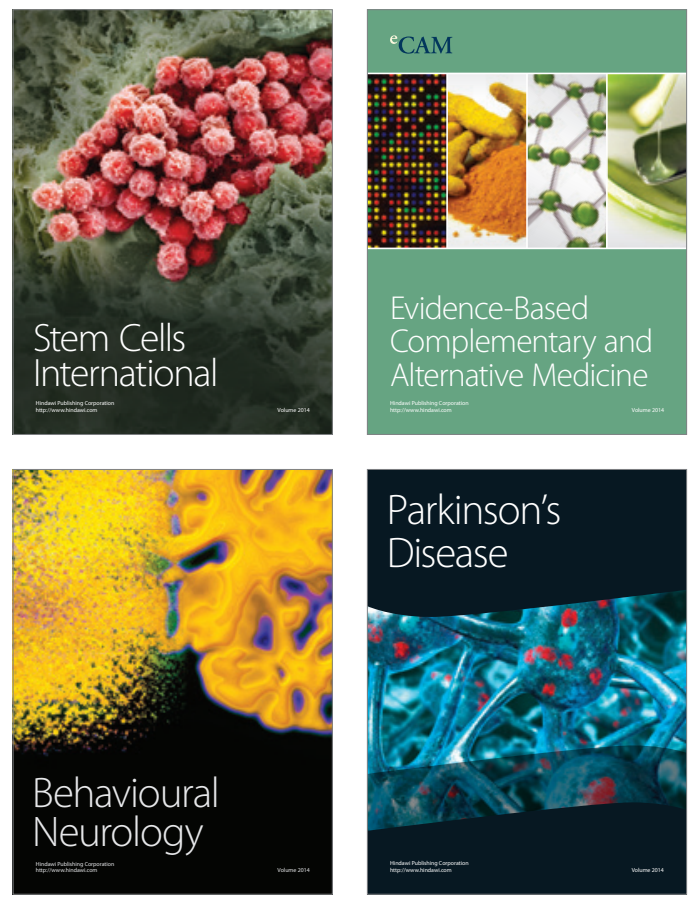
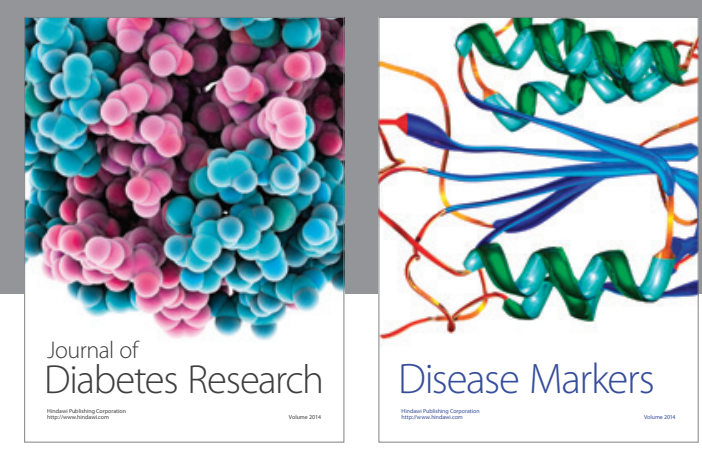

Disease Markers
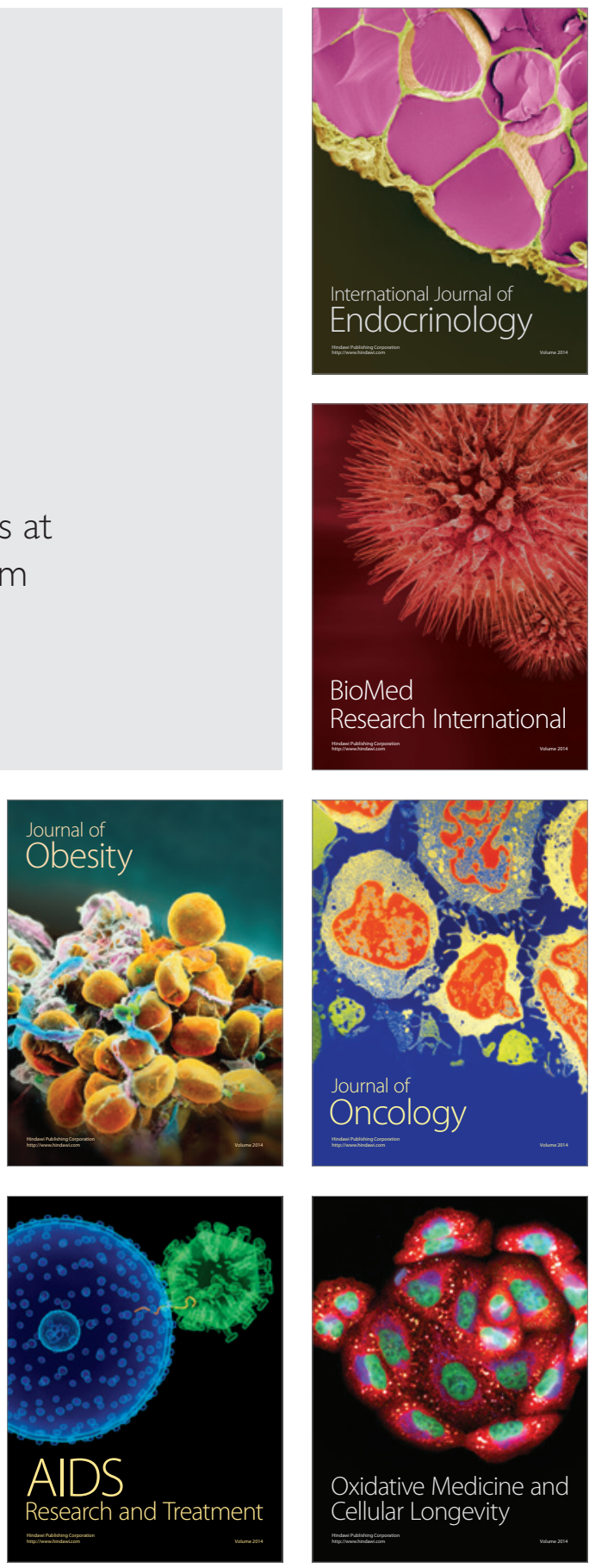